\title{
Richard III - the final act
}

\author{
A. Rai ${ }^{1}$
}

IN BRIEF
Develop a greater understanding of
dentistry at the time of Richard III.
- Appreciate the role Richard III's dentition
played in confirming his identity.
- Acquire a greater understanding of
oral health inequalities at the time of
Richard III.
Comprehend how the analysis of Richard
III's skull and dentition helped to provide
an insight into his lifestyle and final
moments.

On 4 February 2013 experts confirmed that the remains of the last English king to die in battle were found under a council car park in Leicester, England. Richard III, the last Plantagenet king, wore the crown from 1483 until his untimely death in 1485. There have been many myths published about him, even one with a dental reference. This paper explores what dentistry was like at the time of Richard III, reveals the truth behind the myths and sees how the University of Leicester's findings about his dentition and skull has provided an insight into his identification, lifestyle and final moments.

\section{INTRODUCTION}

Richard was born in Fotheringhay Castle, Northamptonshire, on 2 October 1452 to Richard Plantagenet, 3rd Duke of York, and Cecily Neville. In 1483 Richard succeeded his nephew Edward V to the throne and during his short reign reformed the jury system introducing the presumption of 'innocent until proven guilty'. On 22 August 1485 Henry Tudor, Earl of Richmond, engaged Richard in battle on Bosworth Field in Leicestershire. ${ }^{1}$ With his key lieutenants defecting, Richard was killed in battle, effectively ending the War of the Roses and ushering in the reign of the Tudors. Contemporary accounts suggest that his body was slumped over a horse and carried to Leicester, where he is thought to have been buried at Grey Friars church. However, following the dissolution of the monasteries between 1536 and 1541 by Henry VIII the friary disappeared along with any clear record of Richard's grave. The unmarked and forgotten grave remained undisturbed until September 2012 when it was discovered under a car park in Leicester, the site of the lost Church of the Grey Friars (Fig. 1). The University

'General Dental Practitioner, 39 Perimeade Road, Perivale, London, UB6 7AS

Correspondence to: Dr Amit Rai BDS

Email: drrai@live.co.uk; Tel: +44 7779572444

\section{Refereed Paper}

Accepted 18 March 2013

DOI: 10.1038/sj.bdj.2013.378

${ }^{\circ}$ British Dental Journal 2013; 214: 415-417 of Leicester, which has jurisdiction over the remains, analysed them before announcing on 4 February 2013 that tests proved they were the King's 'beyond reasonable doubt'.

\section{DENTISTRY AT THE TIME OF RICHARD III}

By the high Middle Ages dentistry had entered the monasteries, with monks being the dentists of the day and barbers their dental care professionals. Had Richard III received any dental treatment, however, it would have been likely performed by a skilled barber or surgeon following a series of Papal edicts in 1163 that forbade monks from shedding blood. Although generally unregulated, there is evidence of a body of barbers in existence as early as 1308 and in 1462 Richard's brother Edward IV granted a Charter of Incorporation to the barbers making their practices legal. ${ }^{3}$

The beliefs that underpinned dentistry for around 6,000 years changed in 1386 when Guy de Chauliac wrote Chirurgia Magna, from which the term dentist was coined. ${ }^{4}$ The earliest English medical manuscript of Guy de Chauliac's surgery dates back to c.1460. Guy de Chauliac is also credited with developing the pelican instrument ${ }^{5}$ for extractions, so called on account of its resemblance to a pelican beak. Giovanni de Arcoli (Johanues Arculanus), professor of medicine and surgery at Bologna from 1412 to 1427 was the era's next significant contributor to dentistry. Despite his unfamiliarity with tooth morphology he was the first

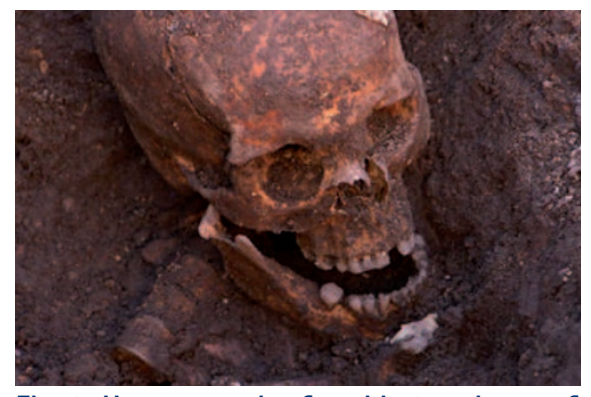

Fig. 1 Human remains found in trench one of the Grey Friars dig. By kind permission of the University of Leicester

to record using gold leaf as a restorative material and considered the preservation of teeth to be important, citing ten rules ${ }^{6}$ in a sort of ancient version of the Department of Health's Delivering better oral health:

1. 'It is necessary to guard against the corruption of food and drink within the stomach; therefore, easily corruptible food - milk, salt fish, etc - must not be partaken of, and after meals all excessive movement, running exercises, bathing, coitus, and other causes that impair the digestion, must also be avoided

2. Everything must be avoided that may provoke vomiting

3. Sweet and viscous food - such as dried figs, preserves made with honey, etc - must not be partaken of

4. Hard things must not be broken with the teeth

5. All food, drink, and other substances that set the teeth on edge must be avoided 
6. Food that is too hot or too cold must be avoided, and especially the rapid succession of hot and cold, and vice versa

7. Leeks must not be eaten, as such a food, by its own nature, is injurious to the teeth

8. The teeth must be cleaned at once, after every meal, from the particles of food left in them; and for this purpose thin pieces of wood should be used, somewhat broad at the ends, but not sharp-pointed or edged; and preference should be given to small cypress twigs, to the wood of aloes, or pine, rosemary, or juniper and similar sorts of wood which are rather bitter and styptic; care must, however, be taken not to search too long in the dental interstices and not to injure the gums or shake the teeth

9. After this it is necessary to rinse the mouth by using by preference a vinous decoctryon of sage, or one of cinnamon, mastich, gallia, moschata, cubeb, juniper seeds, root of cyperus, and rosemary leaves

10. The teeth must he rubbed with suitable dentrifices before going to bed, or else in the morning before breakfast.'

It is not impossible for Richard to have practiced these guidelines relating to oral health, however, it is unlikely that Richard would have had access to a toothbrush or similar instrument. This is because it wouldn't be until after the fifteenth century that natural bristle brushes were routinely used in Europe following their introduction from China.?

\section{TRUTH BEHIND THE MYTH}

In the Rous Roll, written during the reign of King Richard III, scholar John Rous praised the monarch as a 'good lord' who punished 'oppressors of the commons.' However, his views soon changed under the reign of Richard's successor, where in Historia Regum Angliae he demonises Richard III as being born with teeth after having been in his mother's womb for two years. ${ }^{9}$ We know now that it is indeed possible for Richard to have been born with teeth, since the incidence of natal teeth is approximately $1: 2,000$ to $1: 3,000$ live births. ${ }^{10}$ However, it is unlikely that his mother was pregnant for two years, since the human gestation period is normally 38 to 42 weeks!

\section{IDENTITY}

With no surviving dental records relating to Richard III the identity of the Grey Friars skeletal remains had to be confirmed by retrieving DNA samples from the lower left third molar (38), lower left second molar (37) and lower right second molar (47) teeth. Subsequent to the DNA being isolated copies were made using the PCR method with the molecules then split and the code at those points analysed to create a DNA sequence fingerprint. Despite the potential for DNA to degrade a match was found of haplotype J1c2c, one of the rarest types of mitochondrial DNA, between the skeletal remains and two known maternalline descendents of Richard III. ${ }^{2}$ Isolation of a Y chromosome also proved that the skeleton was male.

\section{DENTITION}

Photographs of the skeleton's maxillary teeth show tooth surface loss particularly on the occlusal aspects of the upper left second molar (27), upper right second molar (17) upper right first molar (16) and the incisal edge of the upper right central incisor (11). The cause of this could be attrition due to stress-related bruxism or, more likely, dietary abrasion and erosion. Since the dentine exposure is not severe it is likely that the Grey Friars remains belonged to a higher social rank. This is because we would expect more severe dentine exposure in the less affluent members of society since they would have eaten a coarser, more limited diet of grains that they would have had to chew for a sustained period of time.

Carbon dating of the Grey Friars skeleton has revealed that the diet of the individual was rich in 'significant amounts"2 of protein, particularly marine fish, implying also that the individual had a high status. In medieval times the common person would have been eating pottage and very rarely had access to fresh fish or meat. ${ }^{11} \mathrm{~A}$ diet rich in seafood also has religious connotation based upon the catholic tradition of abstaining from meat on the fifth day of the week meaning that seafood would be consumed instead.

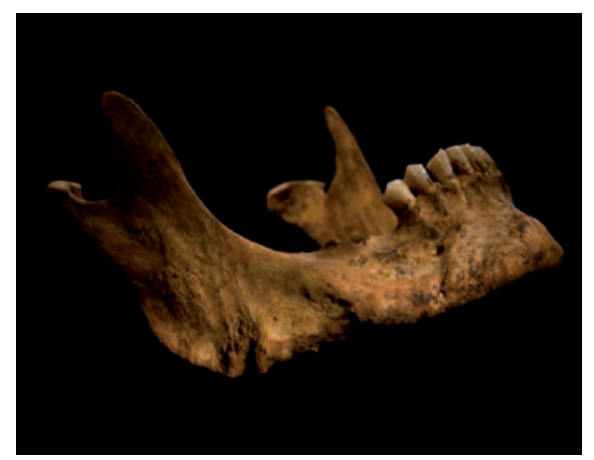

Fig. 2 Right aspect of mandible. By kind permission of the University of Leicester

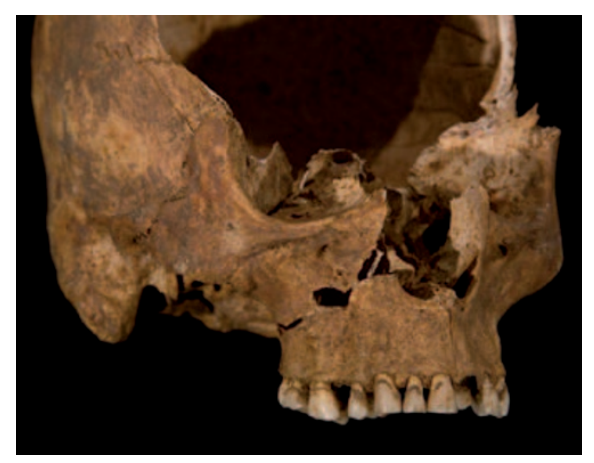

Fig. 3 Front view of skull showing maxillary teeth. By kind permission of the University of Leicester

For the lower social classes access to a limited range of dietary sugars and the consistent inability to cook carbohydrates resulted in a reduced caries experience. ${ }^{12}$ By the same reasoning it is likely that the more affluent of individuals suffered with a greater caries experience, as was the case with the Grey Friars remains where the upper left first molar (26), upper right second premolar (15) and lower right first molar (46) teeth were missing (Fig. 2) most likely due to caries. It is interesting to note that although Figure 2 shows the lower right second molar (47) as missing, Figure 1 does not, since this tooth was extracted post-excavation, along with lower left third molar (38) and lower left second molar (37) for DNA analysis.

There is evidence of gap closure relating to the missing 15 and 36 that could point to the early extraction of these teeth by skilled hands.

Mineralised deposits were found on the labial and buccal surfaces of the maxillary teeth, which would suggest tartar build up over a period of time. It is interesting to note that the upper right central incisor (11) shows less evidence of deposits than the adjacent anterior teeth (Fig. 3) suggesting some degree of insight 
with dental hygiene, however basic. As bacteria become locked away within the calcium phosphate cage of tartar they are able to last for thousands of years. Analysis of this tartar will enable the identification of the strains of bacteria and more specifically the diversity of bacteria which inhabited Richard's mouth, subsequently providing a better insight into his diet and oral hygiene habits.

\section{FINAL MOMENTS}

'A horse! A horse! My kingdom for a horse!'13 these famous words by Shakespeare depict Richard III's final moments on the battlefield, with analysis of the skull revealing death due to trauma. Of the eight wounds found on the skull none of them showed signs of healing, indicating origin around the time of death. Figure 2 shows evidence of a wound seen inferior to the mental foramen from a bladed instrument, and Figure 3 shows a wound on the right aspect of the maxilla. Since the upper left central incisor (21) was missing upon excavation, this could suggest trauma associated avulsion caused around the same time Richard had sustained the wounds to his skull. Richard is likely to have been killed by one of two blows to the base of the skull from some of the most advanced military weapons of the time. ${ }^{2}$ Several accounts of Richard III reveal that he rode into battle wearing his crown which, despite this making him an easy target, is consistent with the location of the battlefield injuries he sustained on his skull.

\section{CONCLUSION}

The provision of dentistry in the fifteenth century was surprisingly sophisticated with evidence of restorative advances. Although mainly unregulated, barbers legally practised dentistry. In contrast to the modern day, Richard lived during a time in which there was less caries experience in the more socially deprived members of society, which somewhat dispels the stereotype of the gap-toothed peasant around this era. Richard's oral health was generally poor with evidence of tartar; however, it is this which may provide the biggest insight into the oral hygiene habits of the time. His dentition has also played an important part in helping to confirm his identity in the absence of dental records. The discovery of Richard III's remains in the twenty first century has enabled advanced scientific analysis to reveal a plethora of information about him and the era in which he lived. Had his remains been discovered in 1914, when the site was sold to Leicester County Council, ${ }^{2}$ he could have been buried in an unmarked grave with his mysteries buried alongside him.

1. Kendall P M. Richard the third. New York: W W. Norton \& Co, 2002

2. The University of Leicester Press Office. The search for Richard III: press pack. Leicester: University of Leicester, 2013. Online information available at http://www2.le.ac.uk/offices/press/media-centre/ richard-iii/ (accessed March 2013).

3. Barber's Historical Society. The history of the Barbers Company. London: Barber's Historical society. Online information available at http://www.barberscompany.org/historical_group.html (accessed March 2013).

4. Shklar G. The dental medicine and surgery of Guy de Chauliac with extended excerpts from the Cyrurgia Magna. J Hist Dent 1997; 45: 113-119.

5. Bennion E. Antique medical instruments. California: University of California Press, 1979

6. Guerini V. A history of dentistry from the most ancient times until the end of the eighteenth century. New York: Lea \& Febiger, 1909.

7. Hyson J M Jr. History of the toothbrush. J Hist Dent 2003; 51: 73-80.

8. Ross C. Richard III. California: University of California Press, 1981.

9. Rous J. Joannis Rossi antiquarii Warwicensis Historia regum angliae. Ulan Press, 2012.

10. Leung A K, Robson W L, Natal teeth: a review. J Natl Med Assoc 2006; 98: 226-228.

11. Newman P B. Daily life in the Middle Ages. North Carolina: McFarland \&t Co Inc, 2001.

12. Grimoud A M, Lucas $S$, Sevin A, Georges $P$, Passarrius O, Duranthon F. Frequency of dental caries in four historical populations from the Chalcolithic to the Middle Ages. Int J Dent 2011; 2011: 519691.

13. Mowat B A, Werstine P (eds). Shakespeare W. Richard III. London: Simon \& Schuster, 2004. 